\title{
Peningkatan Pemahaman dan Keaktifan Siswa Melalui Penerapan Model Pembelajaran Kooperatif Tipe TAI (Teams Assisted Individualization) di SMA Negeri 6 Surakarta
}

\author{
Kismanto 5 \\ kismantoadi@gmail.com
}

\begin{abstract}
This study aims to improve the understanding and active learning of students of opportunity material using cooperative learning models of the TAI (Teams Assisted Individualization). This research is a Classroom Action Research conducted in 2 cycles. Each cycle consists of 4 stages, namely planning, action, observation, and reflection. The research subjects were students of class XII IPA 2 of SMA Negeri 6 Surakarta in the academic year of 2018/2019. The results of the study concluded that the implementation of classroom action through the use of the TAI (Teams Assisted Individualization) type of cooperative learning model on the opportunity material can improve students' understanding and activeness in mathematics learning. This is based on test results and observations. From the test results in the first cycle, the percentage of students who completed was $62.96 \%$ and in the second cycle the percentage of students who completed experienced an increase of $33.33 \%$ to $96.29 \%$. While the observations of the two observers, in the first cycle produced an average percentage of students' activeness reached $66.35 \%$ with a visual activity percentage of $83.2 \%$ and writing activity $61.22 \%$ and in the second cycle an increase in the average percentage of student activity by $20.92 \%$ to $87.27 \%$ with the percentage of visual activity $85.88 \%$, writing activities and activities $88.68 \%$. These results it can be concluded that the application of the TAI (Teams Assisted Individualization) type of cooperative learning model can improve the understanding and activeness of learning in class XII Science 2 SMA Negeri 6 Surakarta odd semester 2018/2019
\end{abstract}

Keywords: Active learning, Teams Assisted Individualization, Activeness

${ }^{5}$ Guru SMA Negeri 6 Surakarta 


\section{PENDAHULUAN}

$K^{s}$ eberhasilan pendidikan dalam proses belajar mengajar dapat dilihat dari kompetensi belajar yang dicapai oleh siswa setelah proses belajar mengajar berlangsung. Kompetensi belajar merupakan pencerminan hasil belajar yang dicapai siswa setelah melakukan usaha belajar. Tinggi rendahnya kompetensi belajar akan memberikan sumbangan dalam mencapai kesuksesan masa depan siswa. Dominasi guru dalam proses pembelajaran menyebabkan siswa tidak banyak berperan dan terlibat secara pasif, . Sebagaimana tugas guru dalam proses belajar mengajar diantaranya sebagai pengelola kegiatan belajar mengajar, fasilisator dalam belajar mengajar dan peranan lainnya yang memang sudah menjadi tuntutan dari seorang guru yang memungkinkan berlangsungnya kegiatan belajar mengajar yang efektif. Sedangkan siswa itu sendiri adalah bertindak sebagai pencari, penerima dan penyimpan isi pelajaran yang dibutuhkan untuk mencapai tujuan yang diinginkan (Hermawan \& Paloloang, 2012).

Berdasarkan hasil pengamatan awal maka disimpulkan bahwa ada kelemahan siswa dari proses pembelajaran matematikaadalah sebagai berikut. 1) rendahnya aktivitas (keterlibatan) siswa dalam kegiatan belajar mengajar. 2) Proses kegiatan belajar mengajar (KBM) belum melibatkan seluruh siswa.3) Kesadaran belajar siswa secara kelompok masih rendah karena sering menggunakan pembelajaran langsung yang hanya mentransfer pengetahuan dari guru ke siswa. 4) kurangnya penghargaan guru atas kerja keras yang dilakukan siswa sehingga semangat untuk belajar matematika kurang.

Untuk membangkitkan motivasi belajar dan keaktifan siswa dalam proses belajar mengajar, maka seorang guru harus bisa memilih model pembelajaran yang tepat. Banyak usaha yang telah dilakukan guru untuk menciptakan kegiatan pembelajaran yang mengaktifkan siswa salah satunya adalah melalui model pembelajaran kooperatif. Kooperatif atau bekerja sama berarti melakukan sesuatu bersama dengan saling membantu dan bekerja sebagai tim (kelompok) (Karim \& Anshariyah, 2016). Model pembelajaran kooperatif merupakan suatu model pembelajaran yang mengutamakan adanya kelompokkelompok. Setiap siswa yang ada dalam kelompok mempunyai tingkat kemampuan yang berbeda-beda (tinggi, sedang dan rendah) dan jika memungkinkan anggota kelompok berasal dari ras, budaya, suku yang berbeda serta memperhatikan kesetaraan jender. Model pembelajaran kooperatif mengutamakan kerjasama dalam menyelesaikan permasalahan untuk menerapkan pengetahuan dan keterampilan dalam rangka mencapai tujuan pembelajaran. Pembelajaran kooperatif tipe TAl (Teams Assisted Individualization) dikembangkan oleh Slavin. Pembelajaran ini mengkombinasikan keunggulan pembelajaran kooperatif dan pembelajaran individual. TAI dirancang untuk mengatasi kesulitan belajar siswa secara individu. Oleh karena itu, kegiatan pembelajarannya lebih banyak digunakan untuk pemecahan masalah, ciri khas pada tipe TAI ini adalah setiap siswa secara individual belajar materi pembelajaran yang sudah dipersiapkan oleh guru. Hasil dari individu dibawa ke kelompok-kelompok untuk didiskusikan dan saling dibahas oleh anggota kelompok, dan semua anggota kelompok bertanggung jawab atas keseluruhan jawaban sebagai tanggung jawab Bersama (Nisa \& Leonard, 2018).

Sehubungan dengan di atas, maka peneliti mempunyai beberapa alasan untuk mencari ide agar dalam pembelajaran matematika dapat berlangsung dengan efektif dan menyenangkan sehingga dapat mencapai hasil yang lebih baik. Alternatif model pembelajaran yang dapat menarik perhatian siswa dalam belajar diantaranya dengan menganjurkan siswa belajar secara kelompok atau dengan menerapkan model pembelajaran kooperatif. Salah satu model pembelajaran matematika adalah pembelajaran kooperatif Teams Assisted Individualization (TAI). Model pembelajaran kooperatif tipe Teams Assisted Individualization (TAI) adalah model pembelajaran kooperatif yang menggabungkan pembelajaran kooperatif dengan pengajaran individual yaitu siswa dituntut menguasai suatu materi secara berkelompok dengan cara mengoptimalkan kemampuan yang dimiliki oleh masing-masing individu untuk bekerja sama dalam sebuah tim (Rohendi, Sutarno \& Waryuman, 2010). Berdasarkan latar belakang tersebut di atas, maka masalah penelitian dapat dirumuskan sebagai berikut :Apakah tingkat pemahaman dan keaktifansiswa dalam proses pembelajaran akan meningkat melalui penerapan model pembelajaran 
kooperatif tipe Teams Assisted Individualization (TAl) pada mata pelajaran matematika unit Peluang pada peserta didik kelas XII IPA 2 di SMA Negeri 6 Surakarta tahun pelajaran 2018/2019?

Tujuan penelitian ini adalah untuk mengetahui apakah pemahaman belajar matematika siswa akan meningkat dengan penerapan model pembelajaran kooperatif tipe Teams Assisted Individualization (TAI) pada mata pelajaran matematikamateri Peluang bagi peserta didik kelas XII IPA 2 SMA Negeri 6 Surakarta tahun pelajaran 2018/2019 dan untuk mengetahui apakah keaktifan belajar matematika siswa akan meningkat dengan penerapan model pembelajaran kooperatif tipe Teams Assisted Individualization (TAI). Manfaat Teoritis, Melalui penerapan pembelajaran kooperatif Teams Assisted Individualization (TAI) dapat meningkatkan motivasi belajar matematika untuk jurusan IPA dan dapat memperbaiki pemahaman konsep Teori Peluang dan operasinya serta dapat mengungkap kesalahan-kesalahan yang dilakukan peserta didk oleh temannya sendiri serta dapat meningkatkan pencapaian kompetensi belajar peserta didik (Sari, Mulyani \& Mulyani, 2014). Belajar adalah suatu proses perubahan tingkah laku individu yang dipengaruhi oleh unsur-unsur yang terkandung di dalamnya (motivasi siswa, bahan belajar, alat bantu belajar, suasana belajar, kondisi subjek belajar) melalui interaksi dengan lingkungannya sebagai hasil pengalaman dan latihan (Nisa \& Leonard, 2018).

\section{METODE PENELITIAN}

Penelitian tindakan kelas ini dilaksanakan di SMA Negeri 6 Surakarta yang terletak di Jl. Mr. Sartono No 30 Telp. (0271) 853209 Surakarta. Subyek penelitian ini adalah peserta didik Kelas XII IPA 2 Tahun Pelajaran 2018/2019.dengan jumlah siswa 30. Penelitian ini dilaksanakan selama enam bulan yaitu bulan Juni 2018 sampai dengan bulan Desember tahun 2018.

Data yang dikumpulkan dalam penelitian penggunaan model pembelajaran kooperatif tipe TAl ini diperoleh dari nilai ulangan atau tes peserta didik dan hasil pengamatan atau observasi. Sedangkan sumber data pada penelitian ini meliputi informasi dari guru dan peserta didik, tempat dan peristiwa berlangsungnya proses pembelajaran, dokumentasi atau arsip berupa silabus dan Rencana Pelaksanaan Pembelajaran (RPP). Dalam penelitian tindakan sekurang-kurangnya terdapat 2 (dua) siklus, mulai dari perencanaan sampai dengan refleksi. Tahapan tersebut diulang sampai sekurang-kurangnya dua kali, dengan catatan bahwa perencanaan pada siklus berikutnya harus didasarkan atas masukan dari siklus sebelumnya, dengan menunjukkan apa saja kelemahan siklus tersebut, kemudian penjelasan tentang bagaimana hal tersebut akan diperbaiki.

Dalam penelitian ini, direncanakan dalam dua siklus.

1. Rancangan Siklus I yang terdiri dari:

Tahap Perencanaan, Pada tahap ini peneliti menyusun beberapa perencanaan: Pembuatan Rencana Pelaksanaan Pembelajaran dan pembuatan instrumen kegiatan,Pemilihan dan penggunaan model pembelajaran kooperatif tipe TAI dengan belajar berkelompok. Jumlah peserta didik dalam satu kelompok 6 orang.Rencana dalam siklus I ini peserta didik akan belajar bersama dengan anggota kelompok

Tahap pelaksanaan, dilaksanakan sesuai skenario pembelajaran yang telah direncanakan yang dilakukan bersamaan dengan observasi terhadap dampak tindakan. (a) Tes penempatan, Guru memberikan tes penempatan kepada peserta didik sebagai acuan dalam pembentukan kelompok heterogen. (b) Membentuk kelompok heterogen, Guru mengelompokkan peserta didik secara heterogen berdasarkan kemampuan akademiknya. (c) Memberikan materi ajar, Guru membagikan materi ajar untuk dipelajari peserta didik. (d) Belajar dalam kelompok, Peserta didik mempelajari materi ajar tentang materi peluang, Peserta didik mengerjakan lembar kerja, Peserta didik melakukan pengecekan lembar kerja secara berpasangan, Setelah seluruh peserta didik dapat menjawab benar lebih dari $50 \%$ soal, peserta didik mengerjakan tes formatif $A$ untuk menilai kriteria kelompok. (e) 
Kelompok pengajaran, Guru memberikan pengajaran kepada peserta didik dari kelompok berbeda. (f) Penilaian dan penghargaan kelompok, Guru melakukan penilaian terhadap kelompok peserta didik dan mengumumkannya pada peserta didik, Guru memberikan penghargaan kepada kelompok Super (Super Team). (g) Informasi materi esensial, Guru mengulas sedikit materi yang telah dipelajari, Guru memberikan kesempatan kepada peserta didik untuk bertanya, Guru menutup pelajaran dengan salam. (h) Tes Unit, Pada akhir materi pembelajaran, guru mengadakan tes unit.

Tahap observasi dan interpretasi, dilakukan dengan mengamati dan menginterpretasikan aktivitas penerapan model pembelajaran kooperatif tipe TAI pada proses pembelajaran matematika tentang kekurangan dan kemajuan aplikasi tindakan pertama untuk mendapatkan data. Dalam hal ini, yang perlu diobservasi adalah keaktifan peserta didik dengan lembar observasi dan kemampuan guru dalam melaksanakan setiap langkah dalam proses pembelajaran berdasarkan rencana pembelajaran yang sudah disiapkan.

Tahap analisis dan refleksi, dilakukan dengan menganalisis hasil observasi dan interpretasi sehingga diperoleh kesimpulan bagian mana yang perlu diperbaiki/disempurnakan dan bagian mana yang telah memenuhi target.

\section{Rancangan Siklus II}

Pada siklus II perencanaan tindakan dengan hasil yang telah dicapai pada tindakan siklus I sebagai upaya perbaikan dari siklus tersebut dengan materi pembelajaran sesuai dengan silabus mata pelajaran matematika, termasuk perwujudan tahap pelaksanaan, observasi dan interpretasi, serta analisis dan refleksi yang juga mengacu pada siklus sebelumnya. Pada siklus II jumlah anggota dalam kelompok diperkecil, sehingga masing-masing anggota kelompok mempunyai kontribusi yang sama dengan anggota kelompok yang lain. Kecuali itu, guru dalam mengadakan pemantauan lebih detail karena anggota dalam kelompok lebih kecil.

\section{HASIL PENELITIAN DAN PEMBAHASAN}

\section{Pra Siklus}

Kondisi awal tingkat pemahaman peserta didik kelas XII IPA 2 SMA Negeri 6 Surakarta juga dapat diukur dari hasil ulangan umum. Berikut merupakan hasil ulangan peserta didik kelas XII IPA 2 SMA Negeri 6 Surakarta pada tiap indikator dengan KKM 70, sebelum digunakan model pembelajaran kooperatif tipe TAI (Teams Assisted Individualization) (pra siklus); Dari nilai ulangan tersebut dapat dibuat tabel presentase capaian peserta didik yang nilainya diatas nilai KKM dan dibawah nilai KKM sebagai berikut.

Tabel 1. Skor Capaian Nilai Pra Siklus

\begin{tabular}{ccc}
\hline \multirow{2}{*}{ Indikator nilai } & \multicolumn{2}{c}{ Pra Siklus } \\
\cline { 2 - 3 } & Jumlah siswa & Presentase (\%) \\
\hline$\geq$ KKM & 12 & 44.44 \\
\hline$<$ KKM & 15 & 55.55 \\
\hline Jumlah & $\mathbf{2 7}$ & $\mathbf{1 0 0}$ \\
\hline
\end{tabular}

Sedangkan tingkat keaktifan peserta didik dilihat dari hasil observasi dengan capaian keaktifan tiap indikator dihitung menggunakan presentase. 
Tabel 2. Presentase Tingkat Keaktifan Peserta Didik Pra Siklus

\begin{tabular}{llcc}
\hline No. & \multicolumn{1}{c}{ Kegiatan Yang Diamati } & Jumlah Siswa & Presentase \\
\hline 1. & Kegiatan visual & 15 & $55,56 \%$ \\
\hline 2. & Kegiatan lisan & 6 & $21.70 \%$ \\
\hline 3. & Kegiatan menulis & 12 & $40.74 \%$ \\
\hline
\end{tabular}

Dapat dilihat pada tabel tersebut bahwa nilai ulangan matematika peserta didik dalam proses pembelajaran yang berlangsung di kelas untuk pra siklus berkisar antara 0-100, dengan nilai rata-rata adalah 59.26. sedangkan dari tabel 1 diatas yang memiliki nilai dibawah KKM mencapai 55.55\%. Dapat dilihat pada tabel tersebut bahwa tingkat keaktifan peserta didik dalam proses pembelajaran yang berlangsung di kelas untuk pra siklus berkisar pada kegiatan visual adalah $55.56 \%$ kegiatan lisan adalah $21.70 \%$ dan kegiatan menulis adalah $40.74 \%$ dengan nilai rata-rata adalah $39.50 \%$.

\section{Siklus I}

a. Perencanaan Tindakan I

Siklus I dilakukan dalam 4 kali pertemuan. Perencanaan tindakan untuk siklus I meliputi hal-hal sebagai berikut :

1) Penyusunan Rencana Pelaksanaan Pembelajaran (RPP) pertemuan 1, 2, 3 dan 4 dengan indikator belajar yang meliputi ruang sampel dan kejadian. (RPP terlampir)

2) Penyusunan ringkasan materi, lembar kerja peserta didik, tes formatif $A$, tes formatif $B$ dan tes unit sebagai tes akhir siklus.

3) Penyusunan lembar observasi proses pembelajaran.

\section{b. Pelaksanaan Tindakan}

Dari 27 siswa yang mengikuti tes unit siklus I, ada 10 siswa yang memiliki nilai dibawah KKM, sehingga perlu adanya remediasi. Sehingga dapat dibuat tabel sebagai berikut

Tabel 3. Skor Capaian Nilai Tes Unit (Tes Akhir Siklus 1)

\begin{tabular}{cccccc}
\hline \multirow{2}{*}{$\begin{array}{c}\text { Indikator } \\
\text { nilai }\end{array}$} & \multicolumn{2}{c}{ Pra Siklus } & \multicolumn{2}{c}{ Siklus 1 } & Peningkatan \\
\cline { 2 - 5 } & $\begin{array}{c}\text { Jumlah } \\
\text { siswa }\end{array}$ & $\begin{array}{c}\text { Presentase } \\
(\%)\end{array}$ & $\begin{array}{c}\text { Jumlah } \\
\text { siswa }\end{array}$ & $\begin{array}{c}\text { Presentase } \\
(\%)\end{array}$ & $\begin{array}{c}\text { (\%) } \\
\geq \text { KKM }\end{array}$ \\
\hline$<$ KKM & 12 & 44.44 & 17 & 62.96 & 18.52 \\
\hline Jumlah & $\mathbf{2 7}$ & 55.55 & 10 & 37.04 & -18.51 \\
\hline
\end{tabular}

Dari tabel 3 diketahui bahwa siswa yang memiliki nilai tes akhir (tes unit) siklus 1 dibawah KKM mencapai 37.04\%. Siswa yang memiliki nilai dibawah KKM setelah adanya tindakan siklus 1 mengalami penurunan sebesar $18.51 \%$ menjadi $37.04 \%$. Sedangkan dari nilai pra siklus dapat dilihat juga bahwa 
siswa yang memiliki nilai diatas KKM meningkat $18.52 \%$ setelah adanya tindakan pembelajaran dengan model pembelajaran kooperatif tipe TAI (Team Assisted Individualization). Siswa yang memiliki nilai diatas KKM sebelum adanya tindakan mencapai $44.44 \%$, setelah adanya tindakan, siswa yang memiliki nilai diatas KKM mencapai $62.96 \%$.

c. Hasil Observasi Tingkat Keaktifan Siswa

Hasil Observasi terhadap tingkat keaktifan siswa setelah penggunaan model pembelajaran kooperatif tipe TAI (Team Assisted Individualization) pada subpokok bahasan ruang sampel dan kejadian dalam pembelajaran pada pra siklus dan siklus I dapat dilihat pada Tabel 4 dan 5 di bawah ini

Tabel 4. Skor Capaian Presentase Setiap Aspek Tingkat Keaktifan Siswa Pra Siklus dan Siklus I

\begin{tabular}{llcc}
\hline \multirow{2}{*}{ No. } & \multirow{2}{*}{ Kegiatan yang diamati } & \multicolumn{2}{c}{ Capaian Presentase } \\
\cline { 3 - 4 } & & Pra Siklus & Siklus I \\
\hline 1. & Kegiatan visual & $55.56 \%$ & $83.2 \%$ \\
\hline 2. & Kegiatan lisan & $21.70 \%$ & $54.65 \%$ \\
\hline 3. & Kegiatan menulis & $40.74 \%$ & $61.22 \%$ \\
\hline
\end{tabular}

Tabel 5. Rentang (Range) Peningkatan Setiap Aspek Tingkat Keaktifan Siswa Pra Siklus dan Siklus I

\begin{tabular}{|l|l|c|c|c|}
\hline \multirow{2}{*}{ No. } & \multirow{2}{*}{ Kegiatan yang diamati } & \multicolumn{3}{|c|}{ Capaian Presentase } \\
\cline { 3 - 5 } & & Pra Siklus & Siklus 1 & Kenaikan \\
\hline 1. & Kegiatan visual & $55.56 \%$ & $83.2 \%$ & $\mathbf{2 7 . 6 4 \%}$ \\
\hline 2. & Kegiatan lisan & $21.70 \%$ & $54.65 \%$ & $\mathbf{3 2 . 9 \%}$ \\
\hline 3. & Kegiatan menulis & $40.74 \%$ & $61.22 \%$ & $\mathbf{2 0 . 4 8 \%}$ \\
\hline
\end{tabular}

\section{d. Hasil Tes Akhir (Tes Unit) siklus I}

Nilai rata-rata kelas 76.59. Nilai tersebut menunjukkan adanya peningkatan jika dibandingkan dengan nilai pada pra siklus maupun nilai rata-rata kelas.

Peningkatan nilai rata-rata dari nilai pra siklus dan nilai hasil tes akhir siklus I, dapat dianalisis menggunakan rumus data kuantitatif dalam penelitian tindakan kelas yaitu:

$$
\begin{aligned}
& P=\frac{\text { PostRate }- \text { BaseRate }}{\text { BaseRate }} \times 100 \% \\
& P=\frac{76.56-59.25}{59.25} \times 100 \%=29.22 \%
\end{aligned}
$$

Nilai rata-rata kelas mengalami peningkatan sebesar $29.22 \%$ setelah dilaksanakan tindakan I. Meningkatnya nilai pada siklus I ini karena telah diterapkannya model pembelajaran kooperatif tipe TAI (Team Assisted Individualization). Tingkat kenaikan nilai tes siswa yang menunjukkan tingkat pemahaman siswa dapat disajikan dalam bentuk diagram sebagai berikut : 


\section{Capaian Prosentase (\%)}

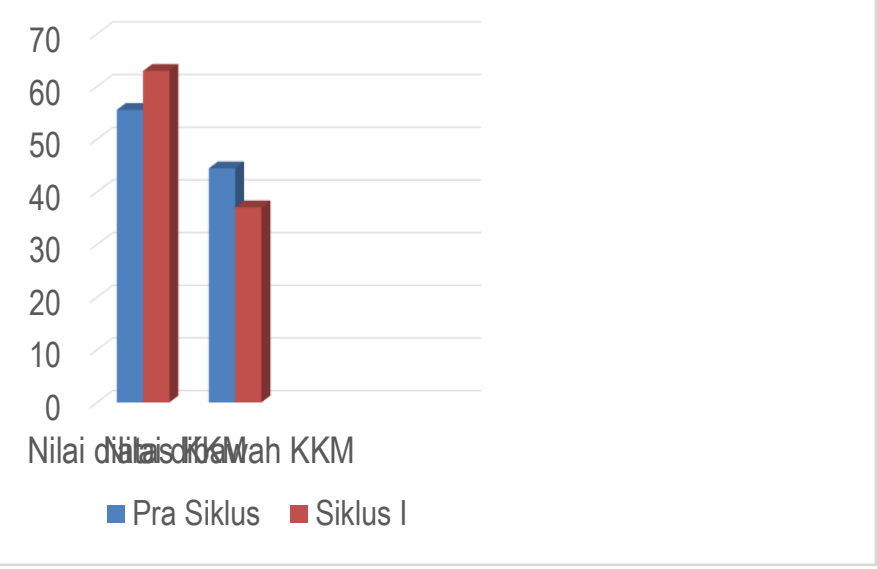

Diagram 1. Presentase Kenaikan Rata-Rata Nilai Setelah Siklus I

Tingkat kenaikan nilai keaktifan siswa yang disajikan dalam bentuk diagram sebagai berikut:

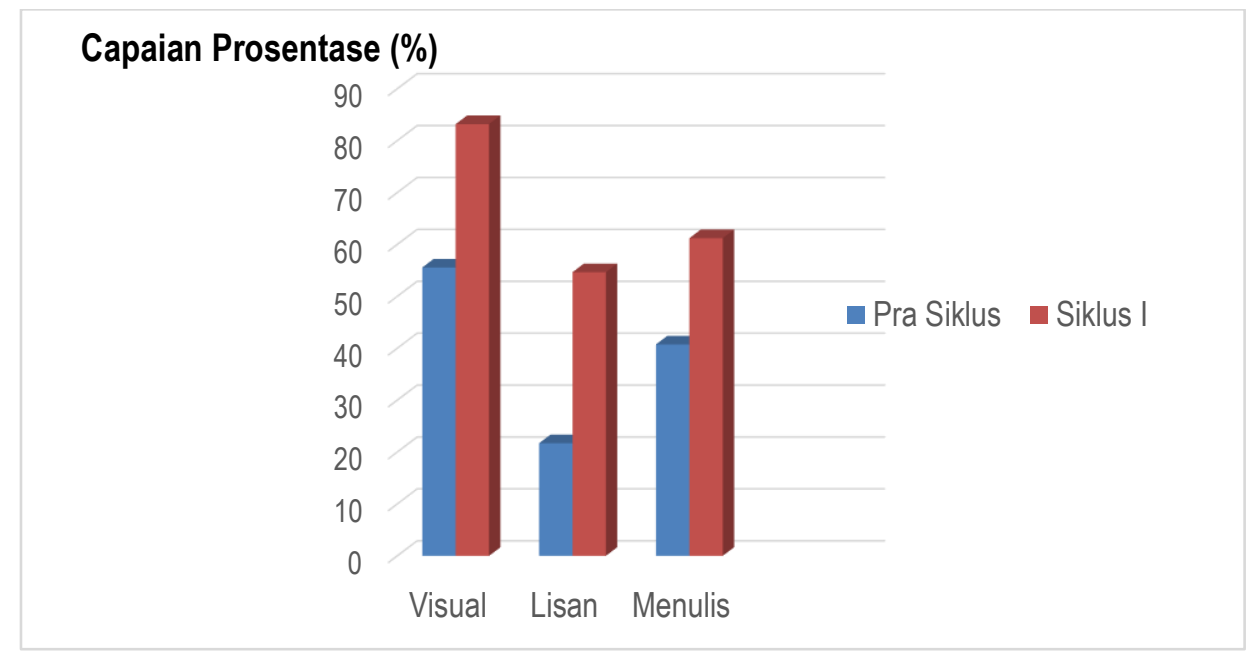

Diagram 2. Presentase Kenaikan Nilai Keaktifan Setelah Siklus I

\section{Siklus II}

\section{a. Perencanaan Tindakan II}

Berdasarkan hasil analisis dan refleksi dari tindakan I, maka perencanaan tindakan untuk siklus II berdasarkan refleksi yang dilakukan pada siklus I meliputi hal-hal sebagai berikut :

1) Dalam pembentukan kelompok, tingkat keheterogenannya kurang merata sehingga dibentuk kelompok baru berdasarkan nilai tes unit siklus I agar persiapan dalam pembentukan kelompok lebih matang. Hal ini dapat dilihat dari daftar kelompok baru pada siklus II dan dilaksanakan ketika proses pembelajaran dalam kelompok. 
2) Mengoptimalkan pemberian motivasi baik pengulangan materi maupun dorongan untuk meningkatkan keaktifan siswa dalam pembelajaran.

3) Memberikan kesempatan kepada siswa untuk banyak bertanya dan menjawab, sedangkan guru hanya bertindak sebagai fasilitator.

4) Menjalankan proses pembelajaran sesuai dengan RPP yang telah direncanakan sehingga alokasi waktunya sesuai danpemusatan perhatian siswa dalam proses pembelajaran sehinggakegaduhan dapat dikurangi.

Siklus II dilakukan dalam 4 kali pertemuan. Perencanaan tindakan untuk siklus II sama dengan yang dilakukan pada siklus I

\section{b. Pelaksanaan Tindakan II}

Pelaksanaan tindakan pada siklus kedua merupakan hasil refleksi dari siklus pertama. Refleksi dari siklus pertama bertujuan untuk mengetahui hal-hal yang dianggap sebagai kekurangan pada tindakan pertama dan membutuhkan adanya perbaikan pada siklus kedua.

\section{c. Observasi dan Evaluasi Tindakan II}

Pada proses pembelajaran yang berlangsung dilakukan penilaian dan observasi terhadap tingkat pemahaman dan keaktifan siswa.

\section{d. Hasil Tes Unit (Tes Akhir) Siklus II}

Hasil tes unit siswa setelah penggunaan model pembelajaran kooperatif tipe TAI (Team Assisted Individualization) pada sub pokok bahasan peluang dalam pembelajaran matematika pada siklus II sebagai berikut :

Tabel 6. Skor Capaian Nilai Tes Unit (Tes Akhir Siklus II)

\begin{tabular}{|c|c|c|c|c|c|}
\hline \multirow[b]{2}{*}{$\begin{array}{l}\text { Indikator } \\
\text { nilai }\end{array}$} & \multicolumn{2}{|c|}{ Siklus I } & \multicolumn{2}{|c|}{ Siklus II } & \multirow[b]{2}{*}{$\begin{array}{c}\text { Peningkatan } \\
(\%)\end{array}$} \\
\hline & $\begin{array}{c}\text { Jumlah } \\
\text { siswa }\end{array}$ & $\begin{array}{c}\text { Presentase } \\
(\%)\end{array}$ & $\begin{array}{l}\text { Jumlah } \\
\text { siswa }\end{array}$ & $\begin{array}{c}\text { Presentase } \\
(\%)\end{array}$ & \\
\hline$\geq \mathrm{KKM}$ & 17 & 62.96 & 26 & 96.29 & 33.33 \\
\hline$<\mathrm{KKM}$ & 10 & 37.04 & 1 & 3.01 & -34.03 \\
\hline Jumlah & 27 & 100 & 27 & 100 & \\
\hline
\end{tabular}

Dari tabel diketahui bahwa siswa yang memiliki nilai tes akhir (tes unit) siklus II dibawah KKM mencapai $3.01 \%$. atau hanya 1 siswa dikarenakan tidak masuk pada pertemuan ketiga siklus II. Sehingga siswa yang memiliki nilai dibawah KKM setelah adanya tindakan siklus II mengalami penurunan sebesar $37.04 \%$ menjadi $34.03 \%$. Sedangkan dari nilai siklus I dapat dilihat juga bahwa siswa yang memiliki nilai diatas KKM meningkat $33.33 \%$ setelah adanya tindakan II pembelajaran dengan model pembelajaran kooperatif tipe TAI (Team Assisted Individualization). 
e. Hasil Observasi Tingkat Keaktifan Siswa

Tabel 7. Skor Presentase Capaian Setiap Aspek Tingkat Keaktifan akhir Siklus II

\begin{tabular}{llccc}
\hline \multirow{2}{*}{ No. } & \multirow{2}{*}{ Kegiatan yang diamati } & \multicolumn{3}{c}{ Capaian Presentase } \\
\cline { 3 - 5 } & & Pra Siklus & Siklus I & Siklus II \\
\hline 1. & Kegiatan visual & $55.56 \%$ & $\mathbf{8 3 . 2} \%$ & $\mathbf{8 5 . 8 8 \%}$ \\
\hline 2. & Kegiatan lisan & $21.70 \%$ & $\mathbf{5 4 . 6 5 \%}$ & $\mathbf{8 7 . 2 6 \%}$ \\
\hline 3. & Kegiatan menulis & $40.74 \%$ & $\mathbf{6 1 . 2 2 \%}$ & $\mathbf{8 8 . 6 8 \%}$ \\
\hline
\end{tabular}

Dari capaian presentase pada tabel dapat dilihat rentangan peningkatan keaktifan siswa sebagai berikut :

Tabel 8. Rentang (Range) Peningkatan Setiap Aspek Tingkat Keaktifan Siswa Siklus I dan Siklus II

\begin{tabular}{llccc}
\hline \multirow{2}{*}{ No. } & \multirow{2}{*}{ Kegiatan yang diamati } & \multicolumn{3}{c}{ Capaian Presentase } \\
\cline { 3 - 5 } & & Siklus I & Siklus II & Kenaikan \\
\hline 1. & Kegiatan visual & $83.2 \%$ & $85.88 \%$ & $\mathbf{2 . 6 8 \%}$ \\
\hline 2. & Kegiatan lisan & $54.65 \%$ & $87.26 \%$ & $\mathbf{3 2 . 6 1 \%}$ \\
\hline 3. & Kegiatan menulis & $61.22 \%$ & $88.68 \%$ & $\mathbf{2 7 . 4 6 \%}$ \\
\hline
\end{tabular}

\section{f. Analisis dan Refleksi Tindakan II}

Peningkatan nilai rata-rata dari nilai pra siklus dan nilai hasil tes akhir siklus II, dapat dianalisis seperti pada siklus I, yaitu:

Nilai rata-rata kelas mengalami peningkatan sebesar $12.04 \%$. Tingkat kenaikan nilai tes siswa yang menunjukkan tingkat pemahaman siswa pada kegiatan pra siklus, siklus I dan siklus II dapat disajikan dalam bentuk diagram sebagai berikut :

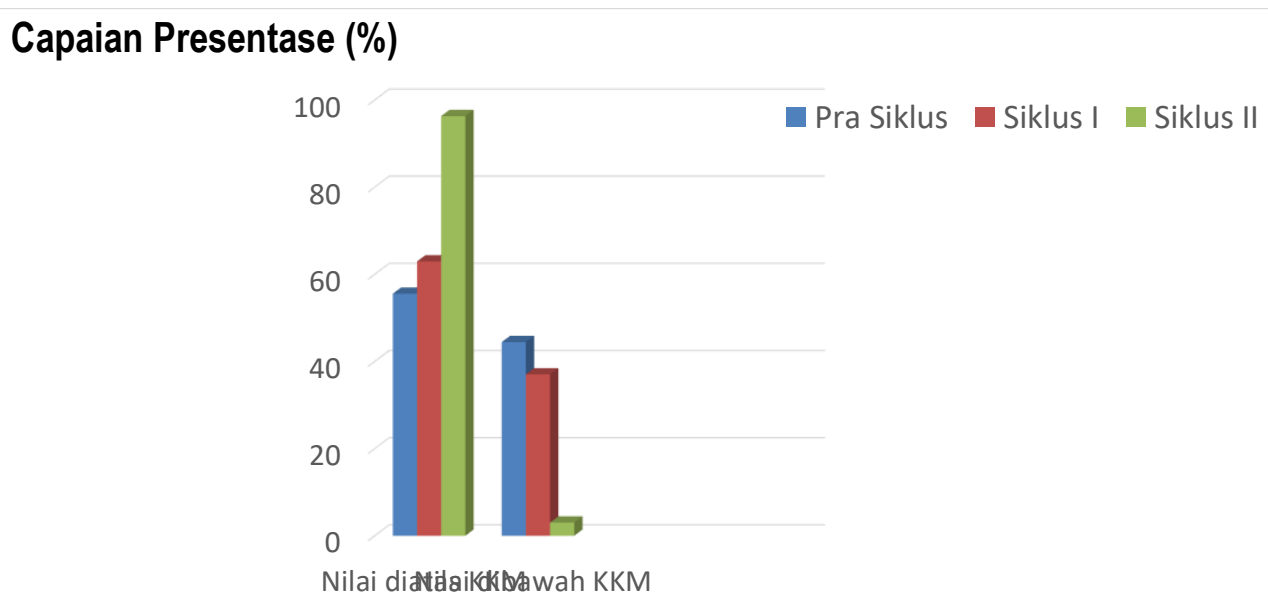

Diagram 3. Presentase Kenaikan Rata-Rata Nilai Setelah Siklus II 
Berdasarkan diagram di atas dapat di lihat bahwa prosentase nilai tes siswa untuk mengetahui tingkat pemahaman siswa mengalami kenaikan dari kegiatan pra siklus, siklus I dan siklus II. Presentase tingkat pemahaman siswa siklus I sebesar $62.59 \%$, setelah adanya perbaikan siklus II tingkat pemahaman siswa meningkat menjadi $96.29 \%$ dengan peningkatan $33.7 \%$.Dalam hal ini, tingkat pemahaman siswa pada siklus II telah mencapai target yang telah ditentukan yaitu sebesar $75 \%$ diatas nilai KKM yakni 77.78. Oleh karena itu tidak perlu dilakukan tindakan selanjutnya.

Tingkat kenaikan nilai keaktifan siswa pada kegiatan pra siklus, siklus I dan siklus II yang disajikan dalam bentuk diagram sebagai berikut:

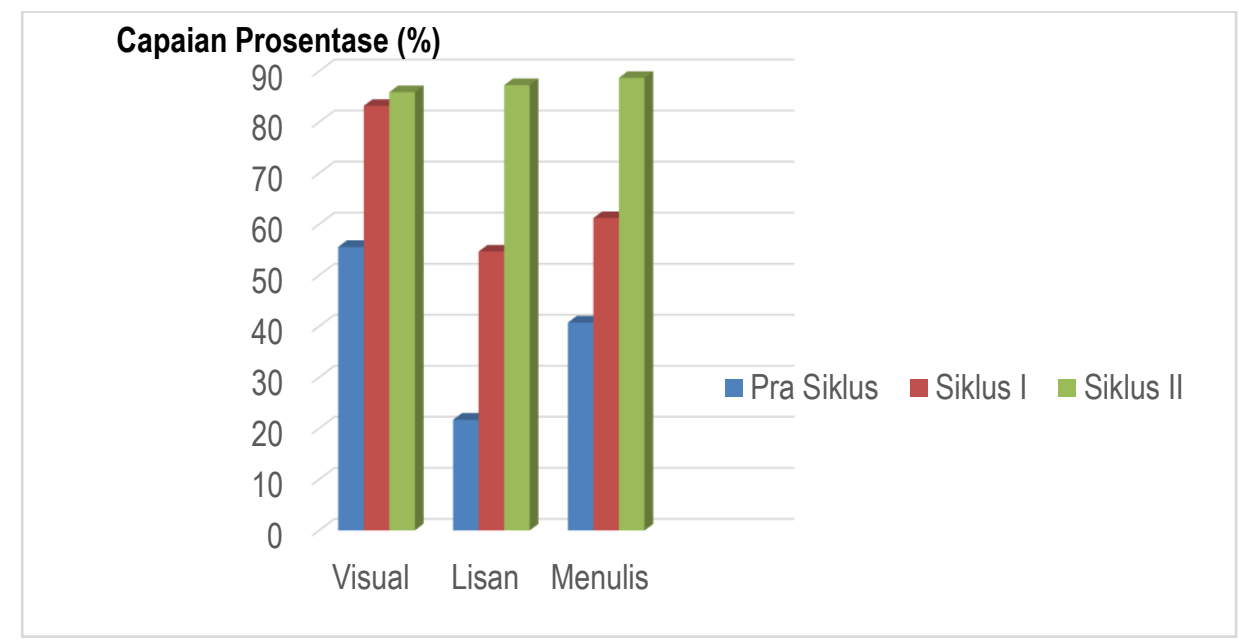

Diagram 4. Presentase Kenaikan Nilai Keaktifan Setelah Siklus II

Seluruh skor dari kegiatan yang diamati mengalami peningkatan dari kegiatan pra siklus ke siklus I maupun dari siklus I ke siklus II. Dari siklus I ke siklus II prosentase kegiatan visual siswa meningkat dari $83.2 \%$ menjadi $85.88 \%$,dengan peningkatan sebesar $2.69 \%$. Prosentase kegiatan lisan meningkat dari $54.65 \%$ menjadi $87.26 \%$ dengan peningkatan sebesar $32.61 \%$. Sedangkan prosentase kegiatan menulis meningkat dari $61.22 \%$ menjadi $88.68 \%$ dengan peningkatan sebesar $27.46 \%$. Dari kegiatan yang diamati, dapat dilihat bahwa hasilnya telah mencapai target yang ditentukan yakni diatas $75 \%$ siswa aktif dari setiap kegiatan tersebut.

\section{KESIMPULAN}

Berdasarkan hasil analisis tersebut dapat disimpulkan bahwa, penggunaan model pembelajaran kooperatif tipe TAI (Teams Assisted Individualization) mampu meningkatkan pemahaman siswa pada mata pelajaran matematika siswa kelas XII IPA 2 SMA Negeri 6 Surakarta tahun pelajaran 2018/2019. Penggunaan model pembelajaran kooperatif tipe TAI (Teams Assisted Individualization) mampu meningkatkan keaktifan siswa pada mata pelajaran matematika siswa kelas XII IPA 2 SMA Negeri 6 Surakarta tahun pelajaran 2018/2019. Dalam kegiatan belajar mengajar, guru hendaknya memberikan bimbingan kepada peserta didik selama pembelajaran berlangsung dan menjadi fasilitator dalam membantu peserta didik yang mengalami kesulitan belajar karena guru memiliki peranan penting terhadap tingkat keberhasilan pembelajaran. Sehingga guru harus berusaha dalam memperbaiki tindak mengajar dan menguasai materi serta strategi pembelajaran yang tepat agar apa yang disampaikan dapat dipahami oleh peserta didik. 
Pelaksanaan model pembelajaran kooperatif tipe TAl (Teams Assisted Individualization) memberikan kesempatan peserta didik dalam mengemukakan ide atau bertanya sehingga dapat menciptakan pembelajaran peserta didik yang aktif.

\section{SARAN}

Kepada peserta didik, hendaknya dalam mengerjakan soal-soal latihan yang diberikanguru dapat terampil dan lebih teliti, karena hal itu mempengaruhi pemahamannya sehinggga prestasinya bisa menjadi meningkat dan peserta didik hendaknya memahami akan pentingnya interaksi dengan orang lain dalam kegiatan belajar kelompok sehingga dapat menumbuhkan keaktifan dalam proses pembelajaran seperti sikap keberanian dalam mengungkapkan pendapat, jawaban maupun pertanyaan selama proses pembelajaran berlangsung sehingga peserta didik mampu mengaktualisasi potensi dan kreativitasnya secara maksimal.

Kepada Guru, hendaknya dapat menggunakan model pembelajaran kooperatif tipe TAI (Teams Assisted Individualization) sebagai salah satu alternatif dalam meningkatkan pemahaman dan keaktifan siswa dan guru diharapkan dapat mengelola kelas dengan efektif, inovatif danmerespon aktif dan kreatif setiap perkembangan pendidikan serta guru dalam menyampaikan materi belajar hendaknya menggunakan variasidalam penggunaan model pembelajaran sehingga peserta didik dengan mudah menerimamateri yang disampaikan sehingga guru mampu mengidentifikasi potensi dan kemampuan peserta didik.

\section{DAFTAR PUSTAKA}

Budiyono. (2003) .Metodologi Penelitian Pendidikan. Surakarta : UNS Press

Gino, dkk. (1998). Belajar dan Pembelajaran 1.Surakarta: UNS press.

Hermawan, H., \& Paloloang, B. (2012). Penerapan Model Pembelajaran Kooperatif Tipe Team Assisted Individualization (TAI) Untuk Meningkatkan Hasil Belajar Siswa Kelas V SDN 4 Bajugan Pada Operasi Hitung Campuran. Jurnal Kreatif Tadulako, 4(9), 44-60.

Karim \& Anshariyah, A. (2016). Penerapan Model Pembelajaran Kooperatif Tipe Team Assisted Individualization (TAI) Untuk Melatih Kemampuan Kemecahan Masalah Katematis Siswa SMA. Jurnal Pendidikan Matematika, 4(1), 58-6

Nisa, K. H \& Leonard. (2018). Model Pembelajaran Team Assisted Individualization dengan Strategi Pembelajaran Tugas dan Paksa. Proseding Seminar Nasional dan Diskusi Panel Multidisiplin Hasil Penelitian \& Pengabdian kepada Masyarakat (pp. 472-484). Jakarta: Universitas Indraprasta PGRI.

Rohendi, D., Sutarno, H. \& Waryuman, D. R. (2010). Penerapan Metode Pembelajaran (TAI) Team Assisted Individualization untuk Meningkatkan Hasil Belajar Siswa Pada Mata Pelajaran Teknologi Informasi Dan Komunikasi. Jurnal Pendidikan Teknologi Informasi dan Komunikasi, 3(1), 33-37.

Sari, D. K., Mulyani, B., \& Mulyani, S. (2014). Studi komparasi metode pembelajaran kooperatif team assisted individualization (TAI) dan cooperative problem solving (CPS) terhadap prestasi belajar ditinjau dari kemampuan matematik siswa pada materi kelarutan dan hasil kali kelarutan kelas XI IPA SM. Jurnal Pendidikan Kimia, 3(1), 51-57

Suwandi, S. (2009). Penelitian Tindakan Kelas (PTK) dan Penulisan Karya IImiah. Surakarta: Panitia Sertifikasi Guru Rayon 13 FKIP UNS. 